\title{
Konseling Religi Untuk Mengembangkan Karakter Konseling
}

\section{Arisatul Maulana dan Hernisawati Institut Agama Islam Ma'arif Nahdlatul Ulama (IAIMNU) Metro Lampung}

\begin{abstract}
Abstrak
Karakter merupakan suatu fondasi kehidupan bangsa. Karakter bagi suatu bangsa memiliki fungsi memberikan arah kemana bangsa harus menuju, bagaimana cara mencapai tujuan itu, apa yang harus dikaji dan dipegang teguh dan sebaliknya apa yang harus dihindari dan dibuang jauh-jauh. Suatu bangsa akan runtuh manakala tidak mempunyai karakter yang kuat. Untuk menjadi bangsa yang maju, modern dan beradab maka diperlukan karakter yang kuat. Dalam artikel ini penulis memaparkan bagaimana konseling memiliki peran yang sangat strategis dalam menjaga dan membentuk karakter peserta didik. Di sekolah pendidikan karakter merupakan proses mengembangkan dalam diri siswa sebuah pemahaman, komitmen, dan kecenderungan untuk berperilaku sesuai dengan nilai-nilai etika. Ada tiga komponen pendidikan yang dapat memastikan berhasil atau tidaknya program pendidikan, yaitu keluarga, masyarakat dan pemerintah (Maba, 2017). Pendidikan karakter mempunyai makna lebih tinggi dari pendidikan moral, karena bukan sekedar mengajarkan mana yang benar dan mana yang salah. Lebih dari itu pendidikan karakter menanamkan kebiasaan (habituation) tentang hal yang baik sehingga siswa didik menjadi mengerti (kognitif) tentang mana yang baik dan salah, mampu merasakan (afektif) nilai yang baik dan mau melakukannya (psikomotor) (Prakoso \& Wahyuni, 2015).
\end{abstract}

\section{PENGANTAR}

Rasulullah SAW menaruh perhatian yang demikian besar terhadap proses pertumbuhan anak sejak kecil (baik anak normal maupun anak yang berkebutuhan khusus) pada usia 0-5 tahun. Rasulullah menyuruh para orang tua memberikan bimbingan, pendidikan, pengawasan dan contoh-contoh yang baik agar tumbuh sifat-sifat terpuji dan sikap santun dalam diri anak sehingga menjadi pembiasaan yang akan tetap dilakukan di fase kehidupan berikutnya. Fase 5 tahun awal kehidupan manusia merupakan fase yang oleh psikologi modern dianggap penting (golden age) dalam pembentukan kepribadian anak. Karena fase anak memiliki pengaruh besar dalam membentuk perilaku dalam menghadapi tantangan kehidupan di masa selanjutnya (Farida, 2012).

Karakter merupakan suatu fondasi kehidupan bangsa. Karakter bagi suatu bangsa memiliki fungsi memberikan arah kemana bangsa harus menuju, bagaimana cara mencapai tujuan itu, apa yang harus dikaji dan dipegang teguh dan sebaliknya apa yang harus dihindari dan dibuang jauh-jauh. Suatu bangsa akan runtuh manakala tidak mempunyai karakter yang kuat. Untuk menjadi bangsa yang maju, modern dan beradab maka diperlukan karakter yang kuat. 
Karakter yang kuat suatu bangsa harus nampak dalam karakter individu setiap warga bangsa dan diwariskan dari satu generasi ke generasi berikutnya lewat pendidikan. Hal ini mempunyai makna bahwa karakter yang kuat tidak akan secara otomatis tumbuh dan berkembang dalam diri masyarakat, sebagaimana generasi-generasi sebelumnya. Di sekolah pendidikan karakter merupakan proses mengembangkan dalam diri siswa sebuah pemahaman, komitmen, dan kecenderungan untuk berperilaku sesuai dengan nilai-nilai etika. Ada tiga komponen pendidikan yang dapat memastikan berhasil atau tidaknya program pendidikan, yaitu keluarga, masyarakat dan pemerintah (Maba, 2017). Pendidikan karakter mempunyai makna lebih tinggi dari pendidikan moral, karena bukan sekedar mengajarkan mana yang benar dan mana yang salah. Lebih dari itu pendidikan karakter menanamkan kebiasaan (habituation) tentang hal yang baik sehingga siswa didik menjadi mengerti (kognitif) tentang mana yang baik dan salah, mampu merasakan (afektif) nilai yang baik dan mau melakukannya (psikomotor) (Prakoso \& Wahyuni, 2015).

\section{MASALAH}

Secara eksplisit, pengembangan karakter religius telah menjadi salah satu fokus kurikulum 2013 yang termaktub dalam program Penguatan Pendidikan Karakter (PPK) (Nindiya \& Sitti, 2017). Nilai karakter religius merupakan poin pertama karakter yang diperkuat sebelum nilai nasionalisme, mandiri, gotong royong dan integritas. Hal ini dikarenakan karakter religius sangat dibutuhkan oleh para peserta didik untuk menghadapi perubahan zaman dengan gambara degradasi moral, dalam hal ini diharapkan peserta didik mampu memiliki dan berperilaku dengan ukuran baik dan buruk yang didasarkan pada ketentuan dan ketetapan agama (Safitri, Saputra, Wonosari, \& Dahlan, t.t.).

Menurut Kemendiknas (2010), religius adalah sikap dan perilaku yang patuh dalam melaksanakan ajaran agama yang dianut, toleran terhadap pelaksanaan ibadah agama lain, dan hidup rukun dengan pemeluk agama lain. Secara umum istilah religius sering diartikan atau identik dengan urusan agama, sehingga menjadi fokus utama dalam pendidikan agama. (Safitri dkk., t.t.) Dalam konsep pendidikan abad 21, menuntut adanya kolaborasi dengan berbagai pihak dalam berbagai kegiatan pendidikan. Kolaborasi adalah kegiatan dimana terjadi kerjasama antara berbagai pihak dalam mewujudkan tujuan pendidikan, baik pihak dari dalam maupun dari luar lembaga pendidikan.(Safitri dkk., t.t.) 


\section{PEMBAHASAN}

\section{Pendidikan karakter}

Pendidikan akhlak (karakter) adalah jiwa pendidikan dalam Islam. Mencapai akhlak yang karimah (karakter mulia) adalah tujuan sebenarnya dari pendidikan Islam. Di samping membutuhkan kekuatan dalam hal jasmani, akal, dan ilmu, peserta didik juga membutuhkan pendidikan budi pekerti, perasaan, kemauan, cita rasa, dan kepribadian (al-Abrasyi, 1987). Sejalan dengan konsep ini maka semua mata pelajaran atau mata kuliah yang diajarkan kepada peserta didik haruslah mengandung muatan pelajaran akhlak (karakter) dan setiap guru atau dosen haruslah memperhatikan sikap dan tingkah laku peserta didiknya (Mishbahuddin, 2017).

Sementara itu karakter menurut Alwisol dalam diartikan sebagai gambaran tingkah laku yang menonjolkan nilai benar-salah, baik-buruk, baik secara eksplisit, maupun implisit. Karakter tersusun dari tiga bagian yang saling berhubungan yakni: moral knowing (pengetahuan moral), moral feeling (perasaan moral) dan moral behavior (perilaku moral). Karakter yang baik terdiri dari pengetahuan tentang kebaikan, (knowing thegood), keinginan terhadap kebaikan (desiring the good) dan berbuat kebaikan (doing the good). Dalam hal ini diperlukan pembiasaan dalam pemikiran (habist of the mind), pembiasaan dalam hati (habits of the heart) dan pembiasaan dalam tindakan (habits of the action) (Mishbahuddin, 2017).

Dari pengertian di atas dapat dipahami bahwa karakter identik dengan akhlak, sehingga karakter merupakan nilai-nilai perilaku manusia yang universal yang meliputi seluruh aktivitas manusia, baik dalam rangka berhubungan dengan Tuhannya, dengan dirinya, dengan sesama manusia, maupun dengan lingkungannya, yang terwujud dalam pikiran, sikap, perasaan, perkataan, dan perbuatan berdasarkan norma-norma agama, hukum, tata karma, budaya, dan adat istiadat. Dari konsep karakter ini muncul konsep pendidikan karakter (character education) (Mishbahuddin, 2017).

Orang berkarakter berarti orang yang berkepribadian, berperilaku, bersifat, bertabiat, atau berwatak. Dengan makna seperti itu berarti karakter identik dengan kepribadian atau akhlak. Kepribadian merupakan ciri, karakteristik, atau sifat khas diri seseorang yang bersumber dari bentukan-bentukan yang diterima dari lingkungan, misalnya keluarga pada masa kecil dan bawaan sejak lahir. Menurut Ryan \& Bohlin, karakter merupakan suatu pola perilaku seseorang. Orang yang berkarakter baik memiliki pemahaman tentang kebaikan, menyukai kebaikan, dan 
mengerjakan kebaikan tersebut.Orang yang perilakunya sesuai dengan kaidah moral disebut dengan berkarakter mulia. Individu yang baik ini bisa membuat keputusan dan siap mempertanggungjawabkan tiap akibat dari keputusan yang dibuat (Isnaini, 2016).

Beberapa ciri orang yang memiliki karakter menurut Howard Kirschenbaum antara lain: hormat, tanggungjawab, peduli, disiplin, loyal, berani, dan toleran. Seseorang yang berkarakter mulia memiliki pengetahuan tentang potensi dirinya, yang ditandai dengan nilai-nilai seperti percaya diri, rasional, logis, kritis, analitis, kreatif dan inovatif, mandiri, hidup sehat, bertanggung jawab, sabar, berhati-hati, rela berkorban, pemberani, dapat dipercaya, jujur, menepati janji, adil, rendah hati, ramah, cinta keindahan (estetis), sportif, dan tabah (Isnaini, 2016).

Menurut David Elkind \& Freddy Sweet Ph.D., pendidikan karakter dimaknai sebagai berikut: "character education is the deliberate effort to help people understand, care about, and act upon core ethical values. When we think about the kind of character we want for our children, it is clear that we want them to be able to judge what is right, care deeply about what is right, and then do what they believe to be right, even in the face of pressure from without and temptation from within” (Isnaini, 2016).

\section{Pendidikan Karakter dalam Perspektif Islam}

Dalam pandangan Islam, pendidikan dalam bahasa Arab bisa disebut dengan istilah tarbiyah yang berasal dari kata kerja rabba, sedangkan pengajaran dalam bahasa arab disebut dengan ta'lim yang berasal dari kata kerja 'allama. Pendidikan Islam sama dengan Tarbiyah Islamiyah. Kata rabba beserta cabangnya banyak dijumpai dalam al-Quran, misalnya dalam Q.S. al-Isra' [17]: 24 dan Q.S. asySyu'ara' [26]: 18, sedangkan kata 'allama antara lain terdapat dalam Q.S. al-Baqarah [2]: 31 dan Q.S. an-Naml [27]: 16. Tarbiyah sering juga disebut ta' dib seperti sabda Nabi SAW.: addabani rabbi fa absana ta'dibi (Tuhanku telah mendidikku, maka aku menyempurnakan pendidikannya). Menurut terminology Islam, pengertian karakter, memiliki kedekatan pengertian dengan pengertian akhlak. Menurut etimologi, kata akhlak berasal dari bahasa Arab, bentuk jamak dari mufradnya khuluq, yang berarti "budi pekerti". Sinonimnya adalah etika dan moral. Etika berasal dari bahasa latin, etos yang berarti kebiasaan. Moral juga berasal dari bahasa latin, mores yang berarti kebiasaannya. Dalam kalimat khuluq mengandung segi-segi persesuaian dengan perkataan khalaqun yang berarti kejadian, serta erat hubungannya khaliq yang berarti penciptaan dan makhluq yang berarti diciptakan (Isnaini, 2016). 
Menurut Abd. Hamid sebagaimana dikutip Zubaedi menyatakan bahwa "Akhlak ialah segala sifat manusia yang terdidik”.19 Memahami pernyataan tersebut dapat dimengerti bahwa sifat atau potensi yang dibawa manusia sejak lahir, maksudnya potensi ini sangat tergantung bagaimana cara pembinaan dan pembentukannya. Apabila pengaruhnya positif, maka sama seperti pendidikan karakter, pendidikan akhlak juga outputnya adalah akhlak mulia dan sebaliknya apabila pembinaannya negatif, yang terbentuk adalah akhlak mazmumah (Isnaini, 2016).

Maka dari itu al-Ghazali mendefinisikan akhlak sebagai berikut: "Akhlaq adalah suatu perangai (watak/tabiat) yang menetap dalam jiwa seseorang dan merupakan sumber timbulnya perbuatan-perbuatan tertentu dari dirinya secara mudah dan ringan tanpa dipikirkan atau direncanakan sebelumnya" (Isnaini, 2016).

Seperti dijelaskan di atas bahwa karakter identik dengan akhlak. Dalam perspektif Islam, karakter atau akhlak mulia merupakan buah yang dihasilkan dari proses penerapan syariah (ibadah dan muamalah) yang dilandasi oleh fondasi aqidah yang kokoh. Ibarat bangunan, karakter/akhlak merupakan kesempurnaan dari bangunan tersebut setelah fondasi dan bangunannya kuat. Jadi, tidak mungkin karakter mulia akan terwujud pada diri seseorang jika ia tidak memiliki aqidah dan syariah yang benar. Seorang Muslim yang memiliki aqidah atau iman yang benar pasti akan mewujud pada sikap dan perilaku seharihari yang didasari oleh imannya (Isnaini, 2016).

\section{Pembentukan karakter.}

Pendidikan adalah usaha membina dan mengembangkan pribadi manusia dari aspekaspek rohaniah dan jasmaniah juga harus berlangsung secara bertahap. Oleh karena suatu kematangan yang bertitik akhir pada optimalisasi perkembangan/ pertumbuhan, baru dapat tercapai bilamana berlangsung melalui peroses demi peroses kearah tujuan akhir perkembangan atau pertumbuhannya.3Lebih spesifiknya, menjadikan pendidikan sebagai upaya, latihan dan sebagainya untuk menumbuh kembangkan segala potensi yang ada dalam diri manusia baik secara mental, moral dan fisik untuk menghasilkan manusia yang dewasa dan bertanggung jawab sebagai makhluk yang berbudi luhur.Dalam kata lain, pendidikan merupakan upaya yang terencana dalam proses pembimbingan dan pembelajaran bagi individu agar berkembang dan tumbuh menjadi manusia yang berakhlak (berkarakter) mulia. Dijelaskan pula, bahwa 
pembentukan karakter yang terdapat dalampasal I UU SISDIKNAS tahun 2003 yang menyatakan bahwa diantara tujuan pendidikan nasional adalah mengembangkan potensi peserta didik untuk memiliki kecerdasan, kepribadian, dan akhlak mulia. Amanah UU SISDIKNAS tahun 2003 itu bermaksud agar pendidikan tidak hanya membentuk insan indonesia yang cerdas, namun juga berkepribadian atau berkarakter. Sehingga, lahir generasi bangsa yang tumbuh berkembang dengan karakter yang bernapas nilai-nilai luhur bangsa serta agama (Isnaini, 2016).

Lebih lanjut disebutkan bahwa untuk kemajuan Negara Republik Indonesia, diperlukan karakter yang tangguh, kompetitif, berakhlak mulia, bermoral, bertoleran, bergotong royong, patriotik, dinamis, berbudaya, dan berorientasi Iptek berdasarkan Pancasila dan dijiwai oleh iman dan takwa kepada Tuhan Yang Maha Esa. Karakter yang berlandaskan falsafah Pancasila artinya setiap aspek karakter harus dijiwai ke lima sila Pancasila secara utuh dan komprehensif meliputi: 1) bangsa yang ber-Ketuhanan Yang Maha Esa, 2) bangsa yang menjunjung kemanusiaan yang adil dan beradab, 3) bangsa yang mengedepankan persatuan dan kesatuan bangsa, 4) bangsa yang demokratis dan menjunjung tinggi hukum dan hak asasi manusia, dan 5) bangsa yang mengedepankan keadilan dan kesejahteraan. Oleh Kemendiknas, telah diidentifikasi 18 nilai karakter yang perlu ditanamkan kepada peserta didik yang bersumber dari Agama, Pancasila, Budaya, dan Tujuan Pendidikan Nasional. Kedelapan belas nilai tersebut adalah: 1)religius, 2) jujur, 3) toleransi, 4) disiplin, 5) kerja keras, 6) kreatif, 7) mandiri, 8) demokratis, 9) rasa ingin tahu, 10) semangat kebangsaan, 11) cinta tanah air, 12) menghargai prestasi, 13) bersahabat/komunikatif, 14) cinta damai, 15) gemar membaca, 16) peduli lingkungan, 17) peduli sosial, 18) tanggungjawab (Islam, 2011).

\section{Cara Membentuk Karakter Anak}

Pembentukan karakter anak sejak usia dini perlu dilakukan secara terus menerus melalui tindakan dan perilaku yang baik. Langkah-langkah yang bisa dijadikan panutan/contoh oleh keluarga atau orang tua dalam membentuk karakter anak adalah sebagai berikut :

a. Mengenali Karakter Anak

Karakter merupakan ciri-ciri anak dalam bersikap dan berperilaku yang mapan. Anak yang berkarakter kepribadiannya dapat diandalkan, dinerhirungkan, dipercaya. Oleh karena itu orang tua harus memahami bahwa karakter berhubungan dengan tiga hal yang sangat terkait, 
yaitu 1) Pengetahuan tentang moral, 2) Perasaan tentang moral dan 3) Perilaku bermoral. (Prasetiawan, 2016).

b. Mengembangkan Karakter Anak

Orang tua yang berkarakter akan membentuk anak-anaknya berkarakter pula. Untuk mengembangkan karakter anak, orang tua sebaiknya memperhatikan beberapa hal sebagai berikut 1) Mendidik anak balita berbeda dengan mendidik anak remaj a atau dewasa; 2) Mendidik anak balita lebih dititikberatkan pada penanaman nilai-nilai moral keagamaan, budi pekerti, etika dan adat istiadat yang berlaku; 3) Mendidik anak balita tidak dengan mengajarkan kata-kata atau menceramahinya; 4) Mendidik anak balita tidak dengan cara kekerasan atau memarahinya atau dibawah ancaman; 5) Mendidik anak balita hams dengan penteladanan orang tua dan percontohan sikap dan perilaku; 6) Mendidik anak balita tidak sekali jadi melainkan hams berkelanjutan hingga karakter anak itu terbentuk (Prasetiawan, 2016).

c. Penguatan Karakter Anak

Tahap berikutnya untuk membentuk karakter anak, yaitu melalui penguatan agar sikap dan perilaku anak tetap/tidak berubah (konsisten) dalam tindakan sehari harinya. Orang tua dapat memberikan penguatan sikap dan perilaku anak, agar karaktemya terbentuk melalui cara sebagai berikut 1) Memberikan pujian pada anak apabila bersikap dan berperilaku sesuai dengan moral dan norma-norma; 2) Apabila sikap dan perilaku anak belum terbentuk, sebaiknya orang tua terns berupaya membimbing anak hingga anak itu bersikap dan berperilaku baik; 3) Orangtua dan anggota keluarga lainnya disarankan tidak memberikan hukuman atau memarahinya sehingga menjadikan anak merasa takut untuk bertindak; 4) Orang tua seharusnya memberi contoh yang baik dan menjadi teladan bagi anak didalam keluarga maupun di luar rumah; 5) Membangun hubungan spiritual dengan Tuhan: Membangun hubungan spiritual melalui pelaksanaan ibadah sesuai agamanya. Anak dapat dilatih meniru gerakan berdoa, dan mulai meniru doa pendek sesuai agamanya. Mengimplementasikan hubungan spiritual dalam kehidupan sehari-hari, misalnya diajak untuk memelihata dan menyayangi ciptaan Tuhan; 6) Catatan Aktivitas Anak Sehari-hari Sikap, perilaku dan tindakan anak yang baik atau kurang baik sebaiknya dicatat oleh orang tua. Catatan ini berguna untuk menilai dan mengevaluasi karakter anak. Karakter mana yang sudah terbentuk dan belum terbentuk atau yang perlu mendapat penguatan lebih lanjut. Orang tua perlu mempunyai catatan tersendiri terhadap sikap, perilaku dan tindakan anak dengan cara memperhatikan 
atau mengamatinya. Apabila masih didapatkan sikap, perilaku dan tindakan anak yang menyimpang dari moral dan norma, maka orang tua dapat mengarahkan, mendidik atau memberi teguran. Begitu pun sebaliknya apabila anak sudah berperilaku baik dapat saja orang tua memujinya atau memberikan hadiah jika memungkinkan (Prasetiawan, 2016).

\section{Tiga Metode Efektif Untuk Membentuk Tingkah Laku Positif}

Melalui keteladan, orangtua menjadi contoh nyata bagi anak dalam berbagai hal seperti: berkatajujur, senang membaca, berkata yang baik, sikap dermawan (suka memberi), pergi ke tempat ibadah, menolong orang lain dan tingkah laku baik yang lain. Pembiasaan Tingkah laku yang sudah dicontohkan oleh orangtua akan menjadi tingkah laku yang baik bila ada pengulangan terus-menerus. Orangtua membuatkan jadwal kegiatan bagi anak dari pagi sampai malam dan mengajarkan etika, moral dan kebiasaan yang baik di rumah.

Pemberian penghargaan (hadiah) dan konsekuensi atas tingkah laku anak Jika orangtua ingin tingkah laku yang baik menjadi kebiasaan anak, orangtua harus memberikan penghargaan dalam bentuk pelukan, mengusap kepalanya atau memberi sebuah jeruk atau sepotong kue. Orangtua juga dapat memberi anak hadiah atas tingkah laku baiknya berupa kegiatanjalan-jalan ke rumah nenek, pergi tamasya ke tempat wisata. Sebaliknya jika anak melakukan tingkah laku yang kurang baik atau yang orangtua tidak inginkan, orangtua hams menunjukkan sikap tidak suka sehingga anak tahu bahwa tingkah lakunya tidak benar dan orangtua tidak menyukainya (Prasetiawan, 2016).

\section{Penerapan Nilai-nilai Karakter Berbasis Religi}

Dalam sejarah peradaban Islam, Nabi Muhammad SAW adalah model terbaik dalam berkarakter sekaligus dalam penanaman karakter di kalangan masyarakatnya. Nabi Muhammad berhasil membangun karakter masyarakat Arab menjadi berbalik dari karakter sebelumnya, yakni yang sebelumnya jahiliyah (bodoh dan biadab) menjadi Islami (penuh dengan nilai-nilai Islam yang beradab). Pembinaan karakter ini dimulai dengan membangun aqidah orang-orang Arab selama kurang lebih tiga belas tahun, yakni ketika Nabi masih berdomisili di Makkah dan dilanjutkan dengan pembentukan karakter mereka dengan mengajarkan syariah (hukum Islam) untuk membekali ibadah dan muamalah mereka seharihari selama kurang lebih sepuluh tahun. 
Dengan modal aqidah dan syariah serta didukungdengan keteladanan sikap dan perilakunya, Nabi berhasil membangun masyarakat Arab menjadi masyarakat madani (yang berkarakter mulia).

Para ahli akhlak (karakter) Islam memberikan wacana yang bervariasi dalam rangka pencapaian manusia paripurna (insan kamil) yang dipengaruhi oleh landasan teologis yang bervariasi pula. Di antara tokoh-tokoh karakter tersebut yang ide-idenya relevan banyak dijadikan rujukan dalam pemikiran dan pembinaan karakter dalam Islam adalah Al-Raghib Al-Asfahani dan al-Ghazali. Al-Asfahani menuangkan ide-ide penyucian jiwa (berkarakter mulia) bagi manusia dalam kitabnya yang diberi judul al-Dzari'ah ila Makarim al-Syari'ah. Menurut alAsfahani, landasan kemuliaan agama adalah kesucian jiwa yang dicapai melalui pendidikan dan melakukan kesederhanaan, kesabaran, dan keadilan. Kesempurnaannya diperoleh dari kebijaksanaan yang ditempuh melalui pelaksanaan perintah-perintah agama, kedermawanan dicapai melalui kesederhanaan, keberanian dicapai melalui kesabaran, dan kebenaran berbuat diperoleh melalui keadilan. Itulah keterkaitan yang sangat erat antara agama dengan karakter seseorang. Ditambahkan, bahwa siapa saja yang memenuhi persyaratan tersebut ia akan memperoleh tingkat kemuliaan tertinggi yang oleh al-Quran (QS. al-Hujurat (49: 13) adalah ketakwaan (Mishbahuddin, 2017).

\section{Peran Layanan Bimbingan dan Konseling Islami dalam Membentuk Karakter}

Peran bimbingan konseling adalah pelayanan bantuan untuk peserta didik, baik secara perorangan maupun kelompok agar mandiri dan berkembang secara optimal, dalam bimbingan pribadi, bimbingan sosial, bimbingan belajar, dan bimbingan karier, melalui berbagai jenis layanan dan kegiatan pendukung, berdasarkan norma-norma yang berlaku. Guru bimbingan dan konseling merupakan pendidik kedua setelah keluaga (orang tua) di rumah. Kewenangan yang dimiliki oleh guru bimbingan dan konseling memiliki peranan yang sangat penting bagi optimalisasi pendidikan ramah anak dalam pembentukan karakter anak. Tindakan yang dapat dilakukan oleh guru bimbingan dan konseling adalah mulai dari menjelaskan pendidikan ramah anak dan bagaimana pembentukan karakter tersebut(Prasetiawan, 2016).

Layanan bimbingan dan konseling dilakukan melalui kontak langsung dengan sasaran layanan (konseli/siswa), dan secara langsung berkenaan dengan permasalahan atau kepentingan tertentu yang dirasakan oleh sasaran layanan itu. Layanan yang diberikan diharapkan dapat 
memberikan dampak positif secara langsung kepada sasaran (konseli) yang mendapatkan layanan (Prasetiawan, 2016).

\section{Pembentukan Karakter Melalui Layanan Bimbingan dan Konseling Islami}

Kata dasar dari religius adalah religi yang berasal dari bahasa asing religion sebagai bentuk dari kata benda yang berarti agama atau kepercayaan akan adanya sesuatu kekuatan kodrati di atas manusia. Sedangkan religius berasal dari kata religious yang berarti sifat religi yang melekat pada diri seseorang. Religius sebagai salah satu nilai karakter dideskripsikan oleh Suparlan sebagai sikap dan perilaku yang patuh dalam melaksanakan ajaran agama yang dianut, toleran terhadap pelaksanaan ibadah agama lain, dan hidup rukun dengan pemeluk agama lain. Karakter religius ini sangat dibutuhkan oleh siswa dalam menghadapi perubahan zaman dan degradasi moral, dalam hal ini siswa diharapkan mampu memiliki dan berprilaku dengan ukuran baik dan buruk yang di dasarkan pada ketentuan dan ketetapan agama (Safitri dkk., t.t.).

Glok dan Stark dalam Lies Arifah (2009: 12) membagi aspek religius dalam lima dimensi sebagai berikut: 1) Religious belief (aspek keyakinan), yaitu adanya keyakinan terhadap Tuhan dan segala sesuatu yang berhubungan dengan dunia gaib serta menerima hal-hal dogmatik dalam ajaran agamanya. Keimanan ini adalah dimensi yang paling mendasar bagi pemeluk agama. 2)

Religious practice (aspek peribadatan), yaitu aspek yang berkaitan tingkat keterikatan yang meliputi frekuensi dan intensitas sejumlah perilaku, dimana perilaku tersebut sudah ditetapakan oleh agama seperti tata cara menjalankan ibadah dan aturan agama. 3) Religious felling (aspek penghayatan), yaitu gambaran bentuk perasaan yang dirasakan dalam beragama atau seberapa jauh seseorang dapat menghayati pengalaman dalam ritual agama yang dilakukannya misalnya kekhusyukan ketika melakukan sholat. 4) Religious knowledge (aspek pengetahuan), yaitu aspek yang berkaitan dengan pemahaman dan pengetahuan seseorang terhadap ajaran-ajaran agamanya untuk menambahkan pengetahuan tentang agama yang dianutnya. 5) Religious effect (aspek pengamalan), yaitu penerapan tentang apa yang telah diketahuinya dari ajaran-ajaran agama yang dianutnya kemudian diaplikasikan melalui sikap dan perilaku dalam kehidupan seharihari.(Safitri dkk., t.t.) 


\section{KESIMPULAN}

Karakter merupakan suatu fondasi kehidupan bangsa. Karakter bagi suatu bangsa memiliki fungsi memberikan arah kemana bangsa harus menuju, bagaimana cara mencapai tujuan itu, apa yang harus dikaji dan dipegang teguh dan sebaliknya apa yang harus dihindari dan dibuang jauh-jauh. Suatu bangsa akan runtuh manakala tidak mempunyai karakter yang kuat. Untuk menjadi bangsa yang maju, modern dan beradab maka diperlukan karakter yang kuat.

Karakter yang kuat suatu bangsa harus nampak dalam karakter individu setiap warga bangsa dan diwariskan dari satu generasi ke generasi berikutnya lewat pendidikan. Hal ini mempunyai makna bahwa karakter yang kuat tidak akan secara otomatis tumbuh dan berkembang dalam diri masyarakat, sebagaimana generasi-generasi sebelumnya. 


\section{DAFTAR PUSTAKA}

Farida. (2012). Bimbingan Keluarga dalam Membantu Anak Autis (Kehebatan Motif Keibuan). Konseling Religi, 3(2).

Islam, P. K. (2011). Peran Bimbingan Konseling Islam Dalam Menurunkan Tekanan Emosi Remaja.

Isnaini, R. L. (2016). Penguatan Pendidikan Karakter Siswa Melalui Manajemen Bimbingan Dan Konseling Islam. Manageria: Jurnal Manajemen Pendidikan Islam, 1(1), 35-52.

Maba, A. P. (2017). Mengembangkan Kemampuan Resolusi Konflik Interpersonal Siswa Melalui Bimbingan Kelompok Dengan Teknik Sosiodrama. Open Science Framework. Https://Doi.Org/10.17605/OSF.IO/E9Q2S

Mishbahuddin, A. (2017). Penerapan Pendidikan Karakter Berbasis Religi Dalam Pembelajaran Pendidikan Agama Islam.

Prakoso, E. T., \& Wahyuni, E. N. (2015). Urgensi Self Efficacy Konselor Sekolah Dalam Mengembangkan Pendidikan Karakter Siswa (Penelitian Survey Terhadap Konselor Sekolah Di Kota Malang). Jurnal Inspirasi Pendidikan, 5(1), 644-652.

Prasetiawan, H. (2016). Peran Bimbingan dan Konseling dalam Pendidikan Ramah Anak terhadap Pembentukan Karakter Sejak Usia Dini. Jurnal CARE (Children Advisory Research And Education), Volume 04(Nomor 1).

Safitri, N. E., Saputra, A. D., Wonosari, S. M., \& Dahlan, U. A. (T.T.). Strategi Pengembangan Karakter Religius Siswa Melalui Ruang Toleransi Beribadah. 